\title{
Modelo de suspensão pela cauda e seu efeito em algumas propriedades mecânicas do osso do rato.
}

\author{
Model of tail suspension and its effect in some mechanical properties of the rat bone.
}

\author{
Adriana Valadares da Sillva', José Batista Volpon ${ }^{2}$
}

\section{RESUMO}

A manutenção do metabolismo mineral normal dos ossos é um resultado de vários fatores inclusive das solicitações mecânicas que são aplicadas aos ossos pelas contrações musculares e pela força da gravidade. O propósito desta investigação foi estudar um modelo de suspensão de rato pela cauda que simulasse assim as alterações esqueléticas que podem acontecer em um ambiente de microgravidade. O modelo foi analisado em termos de tolerância do animal e dos efeitos sobre a resistência mecânica do complexo tíbia-fíbula. Após a realização do ensaio de flexão em três pontos, foram obtidos os principais parâmetros mecânicos (carga e deflexão no limite máximo, carga e deflexão no limite elástico, rigidez e resiliência). Foram utilizadas cinqüenta e três ratas fêmeas, distribuídas em quatro grupos conforme o período de suspensão (controle, 7, 14 e 21 dias). 0 modelo de suspensão mostrou-se eficaz com boa adaptação dos animais e promoveu um enfraquecimento significativo nos ossos principalmente no período de 21 dias.

Descritores: Simulação de microgravidade; Osso; Ratos.

\section{INTRODUÇÃO}

Há evidências significativas de que um ambiente destituído de estímulo mecânico produza efeitos diretos na estrutura e função ósseas $^{(6)}$.

De acordo com Johnson ${ }^{(7)}$, períodos de sete ou quatorze dias de ausência de contato com o solo são suficientes para promover alterações ósseas, principalmente naqueles que servem de apoio para o peso corporal como, por exemplo, o fêmur e a tíbia.

Portanto, a remodelação óssea é extremamente sensível a alterações de tensões mecânicas geradas dentro do tecido ósseo.

A aplicação de forças mecânicas durante uma atividade física normal pode ser definida como estímulo mecânico e causa pequenas deformações na arquitetura óssea, o que estimula a osteogênese. A atividade física pode atuar diretamente na formação óssea. Já, a imobilização leva a um processo de reabsorção do osso(5,15).

Estudos do efeito do repouso prolongado no leito sobre o metabolismo do cálcio mostraram que o aumento de cálcio na excreção urinária que ocorre durante um confinamento prolongado ao leito não é devido à inatividade, mas sim à ausência de compressão longitudinal sobre os ossos longos, causada pelo tipo de decúbito(1).

Trabalho realizado no laboratório de Bioengenharia - USP - Ribeirão Preto

1 - Mestre em Bioengenharia e professora - Universidade de Franca Fisioterapia

2 - Professor Associado e Livre Docente- Faculdade de Medicina de Ribeirão Preto

Endereço: Rua Pedro Nunes Rocha 739. Pq. Progresso. Franca-SP

Cep: 14403-093 - Telefone: (016) 37036911/99653949

E-mail: drivaladares@uol.com.br

\section{SUMMARY}

The maintenance of the normal metabolism of minerals in the bone is a result of several factors including the mechanical demands that are applied to the bones by muscle contractions and gravity force. The proposal of this investigation was to study a model of tail suspension of rats thus simulating the skeletal alterations that may occur in a microgravity environment. The model was analyzed in terms of animal tolerance and the ensuing effects on the mechanical resistance of the tibiofibular complex. After a three-point bending test in flexion the main mechanical parameters were obtained, (load and deflection at the ultimate limit, load and deflection at the yielding point, stiffness and resilience). 53 adult female rats were used and distributed in four groups according to the length of time in suspension (control, 7, 14 and 21 days). The model of suspension was efficient with good animals adaptation and it caused a significant weakness of bones mainly in the 21 day period.

Keywords: Weightlessness simulation; Bone; Rats.

\section{INTRODUCTION}

There are significant evidences that an environment with no mechanical stimulus may produce direct effects in the bone structure and function ${ }^{(6)}$.

According to Johnson (7), periods of seven or fourteen days without any ground contact are enough to promote bone alterations, specially in those ones that support the body weight such as the femur and the tibia.

Therefore, the bone remodeling is extremely sensitive to alterations of the mechanical tension generated in the bone tissue.

The use of mechanical forces during a normal physical activity can be defined as a mechanical stimulus that causes small malformations in the bone architecture, stimulating the osteogenesis. The physical activity may directly act in the bone formation. But the immobilization leads to a bone reabsorption process ${ }^{(5,15)}$.

Studies on the effect of the long resting-on-the-bed periods on the calcium metabolism showed that the calcium increase in the urine excretion during this long period of confinement doesn't occur due to the lack of activity. It occurs because of the longitudinal compression on the long bones caused by the type of decubitus ${ }^{(1)}$.

In order to live or explore the environment with its different climates
Work performed in the Bioengineering Laboratory - USP - Ribeirão Preto

1 - Master in Bioengineering and Professor - Universidade de Franca Physiotherapist

2 - Associate Professor - Faculdade de Medicina de Ribeirão Preto

Address: Rua Pedro Nunes Rocha 739. Pq. Progresso. Franca- SP Cep: 14403-093

Phone: (016) 37036911/ 99653949 - E-mail: drivaladares@uol.com.br 
Para que o homem possa viver ou explorar ambientes de diferentes climas ou atmosferas, precisa adaptar-se fisiologicamente a esses ambientes. Inúmeras pesquisas estão sendo realizadas com o intuito de descobrir qual a influência da gravidade na nossa evolução e o papel que ela representa na fisiologia(10).

As experiências realizadas em vôos orbitais são muito limitadas. Por isso a NASA (National Aeronautics and Space Administration) tem realizado diversos estudos na tentativa de determinar os mecanismos de atrofia muscular e desgaste ósseo que acontecem em indivíduos expostos à microgravidade, tentando simular as condições em vôo espacial(13).

Vários modelos foram empregados para simular as modificações que ocorrem em um ambiente de microgravidade. O sistema de elevação pelo corpo e o modelo de suspensão pela cauda do animal são os dois mais utilizados. Kasper et al. ${ }^{\left({ }^{(8)}\right.}$ e Musacchia et al. ${ }^{(12)}$ afirmaram que o modelo ideal seria aquele que permitisse livre mobilidade ao animal, porém com certa restrição aos movimentos dos membros posteriores, ou seja, o modelo de suspensão pela cauda do animal. Nessa situação os membros posteriores dos animais permanecem com livre movimentação, porém sem contato com o solo. De acordo com a pesquisa realizada por Morey-Holton e Globus ${ }^{(11)}$, animais que permanecem em situações de microgravidade simulada apresentam alterações fisiológicas semelhantes a animais que estiveram em vôos espaciais. Portanto, o modelo de suspensão de rato pela cauda é considerado um modelo efetivo para avaliar os mecanismos fisiológicos e celulares do sistema músculo-esquelético, que se alteram em resposta a um novo estímulo.

O comportamento mecânico do osso pode ser estudado pela realização de ensaios mecânicos do tecido ósseo, que são importantes, pois fornecem parâmetros fundamentais sobre a resistência dessas estruturas ${ }^{(4)}$.

O objetivo geral deste estudo foi avaliar um modelo de suspensão de rato pela cauda que simulasse as alterações no esqueleto que ocorrem em um ambiente de microgravidade e analisar sua efetividade em termos de tolerância do animal à repercussão da suspensão sobre a resistência mecânica do osso. E o objetivo específico foi realizar ensaios mecânicos em flexão do complexo ósseo tíbia-fíbula após diferentes tempos de suspensão pela cauda e determinar a variação de algumas de suas propriedades mecânicas.

\section{MATERIAL E MÉTODOS}

O trabalho foi realizado de acordo com as normas da comissão de pesquisa da Faculdade de Medicina de Ribeirão-Preto- USP. Foram utilizadas ratas fêmeas adultas jovens da raça Rattus Norvegicus albinus, variedade Wistar, com peso corporal médio de 250 gramas. Inicialmente os animais foram mantidos em gaiolas comuns, em número de cinco em cada uma e, ao atingirem o peso desejado, foram transferidos para gaiolas individuais especiais. Nestas gaiolas foram mantidos com os membros posteriores suspensos de modo a permitir o apoio apenas com os membros anteriores para a locomoção e acesso à água e à ração.

Os animais foram distribuídos em quatro grupos experimentais, conforme o tipo de tratamento. Sendo que o grupo 1 (controle) foi constituído por animais que não receberam tratamento específico. No grupo 2 os animais permaneceram em suspensão durante 7 dias, no grupo 3 o período de suspensão foi de 14 dias e dias e no grupo 4 a suspensão foi de 21 dias. Todos os animais foram sacrificados após o período e as tíbias associadas às fíbulas foram submetidas ao ensaio mecânico de flexão em três pontos.

\section{Técnica de suspensão}

Para o processo de instalação da suspensão, os animais foram anestesiados com inalação de éter etílico. Inicialmente, a cauda do and temperatures, men need a physiological adaptation. Innumerous investigations have been performed aiming to discover the influence of the gravity in our evolution and its role in physiology ${ }^{(10)}$.

The experiments performed in orbital flights are very limited. Therefore NASA (National Aeronautics and Space Administration) has performed several studies trying to determine the mechanisms of the muscular atrophy and the bone attrition that occur in individuals exposed to microgravity, simulating the space flight conditions ${ }^{(13)}$.

Several models were applied to simulate the alterations that occur in a microgravity environment. The system of elevation by the body and the model of tail suspension of the animal are the most used. Kasper et al. ${ }^{(8)}$ and Musacchia et al. ${ }^{(12)}$ assured that the ideal model would be the one which enabled free mobility of the animal but with a certain restriction of posterior members movements, i.e., the model of tail suspension of the animal.

In this situation, the posterior members of the animal remain with free movements but without ground contact. According to the research performed by Morey-Holton and Globus ${ }^{(11)}$, the animals that remain in simulated microgravity situations present physiological alterations similar to the animals that were in space flights. Therefore, the model of tail suspension of the rat is considered an effective model to evaluate the physiological and cellular mechanisms of the musculoskeletal system that change responding to a new stimulus.

The bone mechanical behavior can be studied by the performance of mechanical tests of the bone tissue that are important because they provide the fundamental parameters on the resistance of these structures ${ }^{(4)}$.

The general aim of this study was to evaluate a model of tail suspension of the rat that could simulate the alterations in skeletal in a microgravity environment analyzing its effectiveness referring to the animal tolerance and the suspension repercussion on the mechanical resistance of the bone. The particular aim was to perform mechanical tests by flexing the tibia-fibula bone complex after different intervals of time of tail suspension in order to determine the variation of some of its mechanical properties.

\section{Material and Methods}

The paper was performed according to the rules of the research committee of the Medical School of Ribeirão Preto - USP. The experiment used female adult young rats, from the race Rattus Norvegicus albinus, variety Wistar and mean weight of $250 \mathrm{gr}$. At first, the animals were maintained in common cages, in number of five in each one. When they reached the ideal weight, they were transferred to special individual cages. In these cages, they were maintained with the posterior members suspended in order to enable the support using the anterior members only for the locomotion and water and ration access.

The animals were divided into four experimental groups, according to the type of treatment. The Group 1 (control) was formed by animals that didn't receive any specific treatment. In the group 2, the animals remained in suspension for 7 days; in the group 3 the suspension period was of 14 days and in the group 4 the suspension was of 21 days. All the animals were killed after this period and the tibias associated with the fibulas underwent the three-point bending mechanical test in flexion.

\section{Suspension technique}

The animals were anesthetized with etilic ether inhalation in order to install the suspension process. At first, the animal tail was washed with water and detergent and after drying, Benjoim tinck was applied in the whole skin. After that, the tail was enfolded by an adhesive spuma (Reston $\otimes$ ) from its origin until the two proximal thirds, approximately, aiming to protect the skin and avoid cutaneous injuries. 
animal foi lavada com água e detergente e, após estar seca, foi aplicada tintura de Benjoim em toda a pele. Em seguida, a cauda foi envolvida por uma espuma adesiva (Restonâ) desde sua origem até os dois terços proximais, aproximadamente, com o objetivo de proteger a pele e evitar lesões cutâneas.

Sobre a espuma adesiva foi aplicada uma tira elástica adesiva que foi tensionada homogeneamente de modo a envolver toda a espuma. Sobre o envoltório da tira elástica foi colocada uma fita elástica estreita que foi fixada por enfaixamentos da tira elástica adesiva e enfaixamentos adicionais de esparadrapo e barbante de modo a formar uma alça que serviu para conectar o animal ao sistema de suspensão.

Em seguida, com o animal ainda anestesiado, a extremidade distal da sua cauda que não estava enfaixada foi amputada com auxilio de uma cisalha, com objetivo de evitar necrose no local durante o período em que o animal fosse permanecer suspenso.

\section{Gaiola utilizada}

O sistema de contenção dos animais foi constituído por uma gaiola composta por duas partes. A parte inferior foi formada por uma caixa com $35 \mathrm{~cm}$ de largura, $35 \mathrm{~cm}$ de comprimento e $21,5 \mathrm{~cm}$ de altura, aberta superiormente, fabricada em acrílico transparente, para permitir melhor visualização e controle do animal. Foi feita uma perfuração na lateral dessa caixa para introdução do bico do reservatório de água.

Sobre essa caixa de acrílico, foi colocada, em posição invertida, uma nova caixa de grade metálica com, $35,5 \mathrm{~cm}$ de largura, $35,5 \mathrm{~cm}$ de comprimento e $24 \mathrm{~cm}$ de altura. Essa caixa superior foi confeccionada com encaixes nas laterais para garantir perfeita fixação com a caixa de acrílico. O componente superior foi utilizado ainda como suporte para o sistema de fixação do animal. As duas gaiolas foram acopladas de modo que ficassem encaixadas pelas aberturas, formando um compartimento único.

O tamanho da gaiola permitiu aos animais livre movimentação com os membros dianteiros, porém mantendo os membros posteriores suspensos, sem apoio no piso da gaiola ou nas laterais.

Após a montagem da gaiola, foi confeccionado um eixo de suspensão O sistema de fixação foi composto basicamente por uma haste rosqueada de aço retilínea, com $40 \mathrm{~cm}$ de comprimento e $4,5 \mathrm{~mm}$ de diâmetro. Na região central dessa haste foi encaixada uma presiIha que tinha, na outra extremidade, um encaixe para a alça elástica que fazia parte do sistema de acoplamento do animal (Figura 1B).

Foi colocada em cada extremidade da haste uma pequena chapa de alumínio fixada com duas "porcas" para delimitar o espaço de movimentação do animal no interior da gaiola (Figura 1C), sendo que o limite de curso para o animal se movimentar foi de $25 \mathrm{~cm}$. Essa haste foi fixada transversalmente na gaiola superior, no maior diâmetro, tendo vários acessórios compostos por porcas, arruelas e porcas borboleta (Figura 1A), com a finalidade de fixá-la às grades da gaiola e permitir o ajuste da excursão lateral e altura de acordo com o tamanho do animal.

Após a preparação e montagem completa da gaiola, os animais foram pesados e colocados em suspensão. A presilha colocada na barra de suspensão foi presa ao elástico fixado à cauda do animal (Figura 2).

No assoalho da gaiola, foi colocada serragem para higienização e também a ração do animal, que foram trocadas diariamente. O fornecimento de água ao animal, como descrito anteriormente, foi feito com a fixação de uma garrafa na parede lateral. Durante a movimentação dos animais acontecia um deslizamento da presilha que permaneceu conectada à cauda e fixada na haste de aço. Os animais puderam, então, movimentar-se em um ângulo de $360^{\circ} \mathrm{com}$ livre acesso à água e à ração e sem se apoiar nas paredes laterais.
Adhesive elastic strip was applied on the adhesive spuma. The strip was tensioned homogeneously enfolding all the spuma. A narrow elastic ribbon was placed on the elastic strip, fixed by bandages of the adhesive elastic strip and additional bandages of court plaster and twine in order to form a handle used to connect the animal to the suspension system.

After that, with the animal still anesthetized, the distal border of its tail that wasn't bandaged was amputated by a shear, aiming to avoid the local necrosis during the period the animal was suspended.

\section{Applied cage}

The restraint system of the animal was constituted by a two-part cage. The lower part was formed by a box with $35 \mathrm{~cm}$ of width, $35 \mathrm{~cm}$ of length and $21,5 \mathrm{~cm}$ of height, open in the upper extremity. It was made in transparent acrylic to enable a better visualization and animal control. It was made a lateral perforation to introduce the water source point.

Another box with metallic bars with 35,5 of width, 35,5 cm of length and $24 \mathrm{~cm}$ of height was placed in an inverted position on this acrylic box. This superior box was made with lateral sockets to assure a perfect fixation of the acrylic box. The superior component was used as a support for the fixation system of the animal. The two cages were connected to fit perfectly by the opening, forming a unique compartment.

The size of the cage enabled the animals to perform free movements using the anterior members but maintaining the posterior members suspended without a support on the cage floor or on the sides.

After assembling the cage, it was made a suspension axle. The fixation system was basically composed by a straight steel twisted shaft, with $40 \mathrm{~cm}$ of length and $4,5 \mathrm{~mm}$ of diameter. In the central part of this shaft, in the other extremity, a clasp was fit with a socket to the elastic handle which was part of the connection system of the animal (Figure 1B).

A small aluminum plate was placed in each extremity of the shaft, fixed by two "nuts" delimiting the movement space of the animal in the cage (Figure 1C). The course limit to the animal movement was of 25 $\mathrm{cm}$. This shaft was fixed transversally in the superior cage, in the larger diameter, and presented several attachments such as nuts, washers and butterfly nuts (Figure $1 \mathrm{~A}$ ) with the proposal of fixing it to the cage bars enabling the adjustment of the lateral excursion and height according to the animal size.

After the preparation and complete assembly of the cage, the animals were weighted and placed in suspension. The clasp placed on the suspension bar was united to the elastic fixed to the animal tail (Figure 2).

Sawdust for the hygiene and also the animal ration were placed on the cage floor and replaced diary. The provision of water to the animal, as previously described, was made by the fixation of a bottle on the lateral wall. During the animal movements, there was a displacement of the clasp that remained connected to the tail and fixed on the steel shaft. The animals could move to a $360^{\circ}$ angle with free access to water and ration and without a support on the lateral walls.

\section{Mechanical Tests}

The rats were weighted and killed by excessive inhalation of sulfuric ether in order to collect the material. After that the posterior members were dissected and weighted; the right and left tibio-fibular units were cleaned and removed from the soft parts around. The tibia and fibula bones remained connected and were distally merged in the rat. Therefore, the periosteum and the articular cartilage of the borders were preserved and the dissection of the muscles was performed carefully in order to avoid bone damages.

After the dissection, the bones were enfolded in a bandage hu- 


\section{Ensaio Mecânico}

Para a coleta do material, os ratos foram pesados e mortos com inalação excessiva de éter sulfúrico. Depois, os membros posteriores foram dissecados e as unidades tíbiofibulares direita e esquerda retiradas e limpas das partes moles circundantes e pesados. Os ossos tíbia e fíbula permaneceram conectados e no rato, são fundidos distalmente. Portanto, o periósteo e a cartilagem articular nas extremidades foram preservados e a dissecação dos músculos foi realizada com cuidado para evitar danos aos ossos.

Após a dissecação, os ossos foram envolvidos em gase umedecida em soro fisiológico e estocados em "freezer" à temperatura aproximada de $-20^{\circ} \mathrm{C}$

\section{Ensaio de flexão em três} pontos

Para os ensaios mecânicos foi utilizada a máquina universal de ensaio do Laboratório de Bioengenharia da Faculdade de Medicina de Ribeirão Preto da Universidade de São Paulo. Vinte e quatro horas antes os ossos foram retirados do "freezer" e mantidos em um refrigerador comum. Algumas horas antes de serem testados, eles foram retirados e mantidos em temperatura ambiente, para entrar em equilíbrio térmico, ainda envolvidos com gases umedecidas em soro fisiológico.

O conjunto tíbia-fíbula de cada lado foi submetido à flexão simples com três pontos de apoio. O ponto de aplicação da carga foi na face posterior da tíbia, sendo que a face anterior permanecia voltada para baixo e a distância entre os pontos de apoio foi de $2,5 \mathrm{~cm}$. Foi aplicada pré-carga de 200 g, com tempo de acomodação de 1 minuto, na direção vertical, de cima para baixo.

A carga foi aplicada a uma velocidade de $0,25 \mathrm{~mm} / \mathrm{min}$ e registrada por uma célula de carga de 200 kgf (Kratos ${ }^{\circledR}$ ) acoplada ao amplificador CAE 201 Sodmex ${ }^{\circledR}$ até que houvesse quebra da tíbia. A fíbula não foi submetida diretamente à carga. Todos os ensaios foram realizados em condições semelhantes e, durante todos eles, os ossos foram mantidos umedecidos em soro fisiológico para evitar o ressecamento.

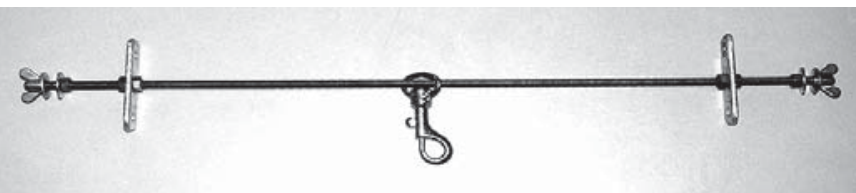

Figura 1A - Eixo de suspensão montado com todos os acessórios. Figure $1 \mathrm{~A}$ - Suspension axle assembled with all the accessories

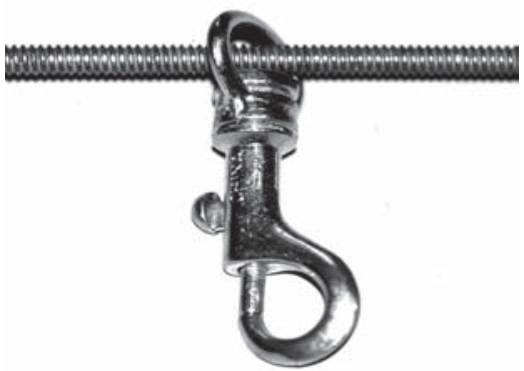

Figura 1B: Detalhe da presilha que desliza no eixo e serve de acoplamento do animal.

Figure 1B - Detail of the clasp which slides in the axle and is used to the animal's connection

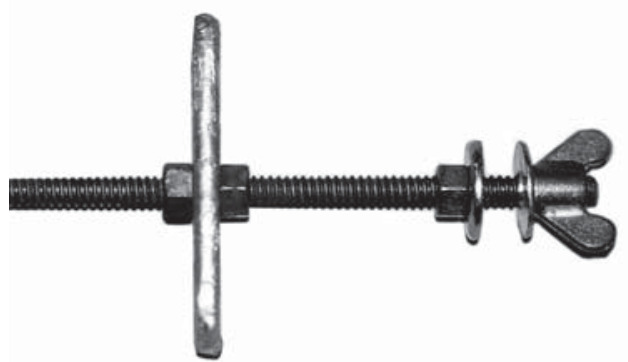

Figura 1C: Detalhe do sistema de bloqueio para delimitação da excursão da presilha.

Figure 1C - Detail of the blocking system to delimit the clasp excursion.

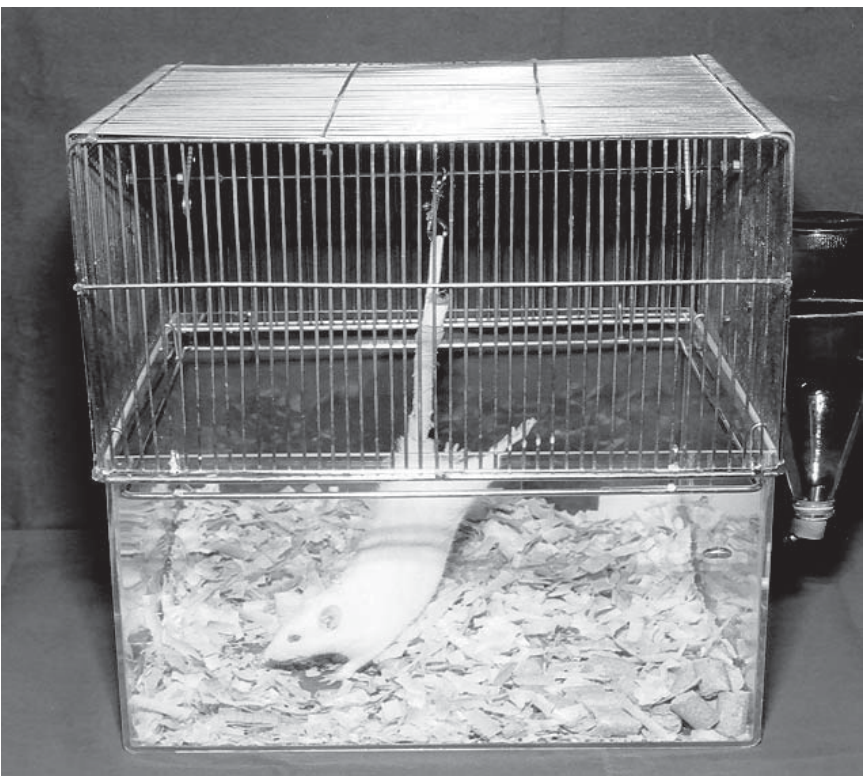

Figura 2 - Vista da gaiola ilustrando todo o sistema de suspensão e o posicionamento do animal.

Figure 2 - View of the cage showing all the suspension system and the animal's position. midified by physiological serum and stocked in "freezer" in an approximate temperature of $-20^{\circ} \mathrm{C}$

Three-point bending mechanical test in flexion

In these mechanical test, it was used a universal test machine of the Bioengineering Laboratory of the Medical School of Ribeirão Preto of the Universidade de São Pau10. 24 hours before, the bones were removed from the "freezer" and kept in a common refrigerator. Some hours before being tested, they were removed and kept under ambient temperature in order to get the thermal equilibrium. They were still enfolded in a bandage humidified by physiological serum.

The tibia-fibula set of each side underwent three-point bending in simple flexion. The load application point was the posterior side of the tibia and the anterior side was turned down. The distance between the support points was 2,5 $\mathrm{cm}$. It was applied a pre-load of $200 \mathrm{~g}$, with an accommodation time of 1 minute, vertically, from top to bottom.

The load was applied in a speed of $0,25 \mathrm{~mm} / \mathrm{min}$ and registered by a load cell of $200 \mathrm{kgf}$ (Kratos $\left.{ }^{\circledR}\right)$ connected to the CAE 201 Sodmex ${ }^{\circledR}$ amplifier, until the tibia fracture. The tibia wasn't directly submitted to the load. All the tests were performed in similar conditions and during all of them the bones were kept humidified by physiological serum in order to avoid drying up.

\section{Mechanical parameters analysis}

To each test, a load $\mathrm{x}$ deflection graphic was built and the following mechanical parameters were obtained: elastic limit, maximum limit, rigidity and the energy absorbed by the bone in the elastic phase (resilience) (Figure 3).

\section{Statistical analysis \\ Animals weight}

The animals weight of the groups 2, 3, and 4, individually, was analyzed before and after the suspension, using the t test of Student paired. 


\section{Análise dos parâmetros mecânicos}

Para cada ensaio foi construído o gráfico carga $x$ deflexão e obtidos os seguintes parâmetros mecânicos: limite elástico, limite máximo, rigidez e a energia absorvida pelo osso na fase elástica (resiliência) (Figura 3).

\section{Análise estatística \\ Pesos dos animais}

O peso dos animais dos grupos 2, 3, e 4, individualmente, foi analisado antes e depois da suspensão, utilizando o teste $t$ de Student pareado.

A comparação estatística dos pesos dos animais antes da suspensão foi realizada aplicando o teste de ANOVA para comparação simultânea entre os grupos e o método de Student-Newman-Keuls para comparação entre os pares de grupos. Os mesmos testes foram aplicados na comparação entre os grupos 2, 3 e 4 após a suspensão.

\section{Pesos das peças}

A comparação estatística dos pesos das peças foi realizada aplicando o teste de ANOVA para comparação simultânea entre os grupos e o método de Student-Newman-Keuls para comparação entre os pares de grupos.

\section{Propriedades mecânicas}

Para a análise estatística da carga e deflexão do limite elástico, deflexão do limite máximo e resiliência foi utilizado o teste ANOVA para comparação simultânea entre os grupos e o método de Student-Newman-Keuls para comparação entre os pares de grupos.

A carga do limite máximo e rigidez apresentaram uma distribuição não paramétrica, portanto, foi aplicado o teste de Kruskal-Wallis para a comparação simultânea entre os grupos e o método de Dunn para comparação entre os pares de grupos. O nível de significância foi estabelecido em $5 \%$

\section{RESULTADOS}

Foram colocados em suspensão 45 animais, sendo que, durante a fase experimental, dois morreram. Estes animais foram os primeiros colocados em suspensão, a extremidade da cauda não foi amputada o que resultou em necrose, devido à compressão excessiva causada pelo sistema de fixação do animal ligado ao eixo de suspensão. Portanto, a morte desses animais pode estar relacionada com a necrose da cauda. Depois, todos os animais tiveram a extremidade da cauda amputada e não surgiram mais complicações.

Portanto, foram ensaiados os ossos tíbia e fíbula direita e esquerda de 43 animais submetidos à suspensão, somando 86 testes. Desses animais 14 pertenciam aos grupos 2 e 3 e 15 ao grupo 4. Foram, também, analisados 10 animais do grupo controle, sendo que, nesses, foram ensaiados apenas o lado direto.

Para obtenção dos resultados finais foram descartados os gráficos que apresentaram comportamentos atípicos o que, geralmente reflete pro-
The statistical comparison of the animals' weight before the suspension was performed by the ANOVA test to simultaneous comparison among the groups and the Student-Newman-Keuls method to compare the pairs of groups. The same tests were applied in comparison to the groups 2, 3 and 4 after the suspension.

\section{Parts weight}

The statistical comparison of the parts weight was performed applying the ANOVA test to simultaneous comparison among the groups and the Student-Newman-Keuls method to compare the pairs of groups.

\section{Mechanical properties}

For the statistical analysis of the load and deflection of the elastic limit, deflection of the maximum limit and resilience, ANOVA test was used to simultaneous comparison among the groups and the StudentNewman-Keuls method to compare the pairs of groups.

The load of the maximum limit and rigidity presented a non-parametrical distribution, therefore it was applied the Kruskal-Wallis test to simultaneous comparison among the groups and the Dunn's method to compare the pairs of groups. The level of significance was settled in $5 \%$

\section{RESULTS}

45 animals were placed in suspension, and two died during the experimental phase. These animals were the first to be placed in suspension. The tail border wasn't amputated resulting in necrosis due to the excessive compression caused by the fixation system of the animal connected to the suspension axle. Therefore, the death of these animals may be related to the tail necrosis. After that, all the animals had their tails extremities amputated and there weren't more complications.

The right and left tibia and fibula bones of 43 animals that underwent suspension were tested, in a total of 86 tests. Of these animals, 14 were from the groups 2 and 3 and 15 from group 4 . Ten animals of the control group were also analyzed and only the right side was tested in these ones.

To obtain the final results, the graphics presenting atypical behaviors were discharged what generally reflects the technical problems occurred during the test. Therefore, of the 96 tests 87 were used for the final analysis.

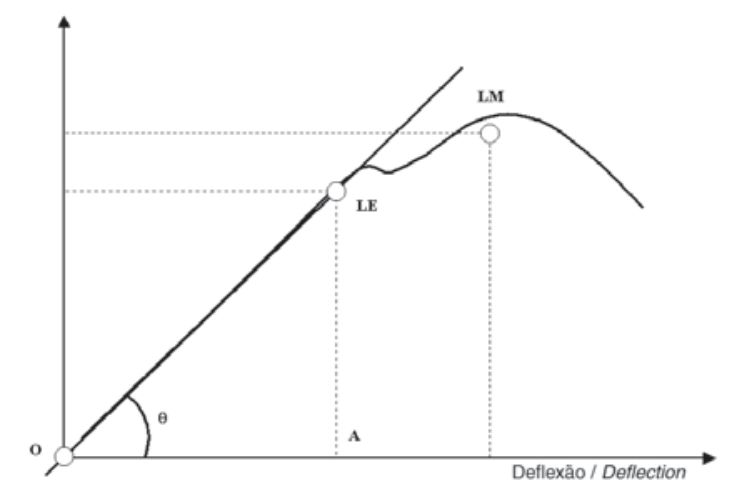

Figura 3 - Gráfico carga x deflexão, a partir do qual são obtidas as principais propriedades mecânicas do ensaio de flexão em três pontos.

Figure 3 - Load $x$ deflection graphic. From this graphic, the main mechanical properties of the essay of flexion in three points are obtained.

\section{Animals weight}

By analyzing the animals weight values, it wasn't observed any statistical difference among the groups at the beginning of the experiment $(p=0,054)$. The mean weight of the animals from the group 1 (control) was 257,3 g; in the group 2, it was $245,1 \mathrm{~g}$; in the group 3, it was $246,8 \mathrm{~g}$ and in the group 4 it was $260,4 \mathrm{~g}$

At the end of the experiment, the overall weight of the group 2 (7 days of suspension) presented a significant statistical difference comparing to group 4 (21 days of suspension). Therefore, between group 2 and group 3 there wasn't any statistical difference as well as between groups 3 and 4. After the suspension, the mean weight of the animals in 
blemas técnicos ocorridos durante o ensaio. Sendo assim, do total de 96 ensaios foram aproveitados 87 para a análise final.

\section{Peso dos animais}

Analisando os valores do peso dos animais, observou-se que não houve diferença estatística entre os grupos no início do experimento $(p=0,054)$. A média de peso nos animais do grupo 1 (controle) foi de 257,3 g, no grupo 2 foi 245,1 g, no grupo 3 foi de 246,8 g e no grupo 4 foi $260,4 \mathrm{~g}$.

No final do experimento o peso do grupo 2 (7 dias de suspensão) global apresentou diferença estatística significante em relação ao grupo 4 (21 dias de suspensão). Porém entre os 2 e grupo 3 não houve diferença estatística, assim como entre os grupos 3 e 4 . Após a suspensão, a média de peso nos animais do grupo 2 foi de 234,3 g, no grupo 3 foi 241,1 g e no grupo 4 foi $256,0 \mathrm{~g}$.

O peso dos animais em cada grupo foi também analisado, antes e após o período de suspensão. O grupo 2 apresentou diferença significativa $(p=0,006)$. No grupo 3 não houve diferença significante $(p=0,061)$ e, no grupo 4 , observou-se que houve diferença significante $(p=0,024)$.

\section{Peso das Peças}

Analisando os valores do peso das peças (tíbia-fíbula), observou-se que houve diferença entre todos grupos $(p=0,0140)$. A média do peso das peças nos animais do grupo 1 (controle) foi de $0,86 \mathrm{~g}$, no grupo 2 foi $0,77 \mathrm{~g}$, no grupo 3 foi $0,79 \mathrm{~g}$ e no grupo 4 foi de $0,76 \mathrm{~g}$. O grupo 1 apresentou diferença quando comparado a todos os outros grupos: Grupo 1 e Grupo $2(p=0,035)$, Grupo 1 e Grupo3 $(p=0,020)$ e Grupo 1 e Grupo $4(p=0,0015)$. Quando comparamos os grupos 2, 3 e 4 não observamos diferença: Grupos 2 e 3 ( $p=0,332)$, Grupos 2 e $4(p=0,948)$ e Grupos 3 e $4(p=0,275)$.

\section{ENSAIO MECÂNICO}

A partir dos gráficos carga $x$ deflexão, foram obtidos os valores das propriedades mecânicas dos ensaios de flexão em três pontos dos ossos tíbia e fíbula do grupo controle e de ratas submetidas aos diferentes períodos de suspensão (7, 14 e 21 dias).

A Figura 4 mostra o valor médio da carga no limite elástico (LE) obtido nos ensaios dos ossos tíbia e fíbula das ratas do grupo 1 (controle) que foi de $(46,75 \pm 5,00) \mathrm{N}$, para o grupo 2 foi $(41,39 \pm 5,59) \mathrm{N}$, para o grupo 3 foi $(37,58 \pm 7,25) \mathrm{N}$ e para o grupo 4 foi $(32,17 \pm 5,27) \mathrm{N}$. A comparação simultânea entre todos os grupos foi estatisticamente diferente $(p=0,009)$. Após análise dos valores da carga no LE foi verificado que houve diferença significante entre o grupo1 (controle) e o grupo $2(p=0,0064)$, entre o grupo 1 (controle) e o grupo3 $(p=0,0085)$ e entre o grupo 1 (controle) e o grupo $4(p=0,0096)$. Podese observar, também, diferença estatisticamente significante entre os grupos 2 e $3(p=0,029)$, entre os grupos 2 e $4(p<0,0011)$ e entre os grupos 3 e 4 $(p=0,002)$

As deflexões no LE no grupo 1 (controle) apresentaram valores médios de $(0,478 \pm 0,046) \times 10^{-3} \mathrm{~m}$, para o grupo 2 $(0,484 \pm 0,075) \times 10^{-3} \mathrm{~m}$, para o grupo 3 $(0,457 \pm 0,099) \times 10^{-3} \mathrm{~m}$, e, para o grupo 4 $(0,455 \pm 0,094) \times 10^{-3} \mathrm{~m}$. A comparação simultânea entre todos os grupos não foi estatisticamente diferente $(p=0,580)$. Comparando os valores das deflexões no LE, foi verificado que não houve diferença estatisticamente significante entre os grupos. Os valores obtidos foram: entre o grupo 1 e o gru- group 2 was 234,3 g, in group 3 was 241, $1 \mathrm{~g}$ and in group 4 was 256,0 g.

The animals' weight in each group was also analyzed, before and after the suspension period. The group 2 presented significant difference $(p=0.006)$. In the group 3 , there wasn't any significant difference $(p=0.061)$ and in the group 4 there was a significant difference $(p=0.024)$.

\section{Parts weight}

By analyzing the parts weight values (tibia-fibula), it was observed a difference among all groups $(p=0,0140)$. The mean parts weight of the animals in the group 1 (control) was 0,86 g, in the group 2 was $0,77 \mathrm{~g}$, in the group 3 was $0,79 \mathrm{~g}$ and in the group 4 was $0,76 \mathrm{~g}$. The group 1 presented difference when compared to all the other groups: Group 1 and Group 2 ( $p=0.035)$, Group 1 and Group $3(p=0,020)$ and group 1 and group $4(p=0.0015)$. When the groups 2, 3 and 4 are compared it isn't observed any difference: groups 2 and $3(p=0,332)$, groups 2 and $4(p=0,948)$ and groups 3 and $4(p=0,275)$

\section{MECHANICAL ESSAY}

From the load $x$ deflection graphic, the mechanical property values of the flexion tests were obtained in three points of the tibia and fibula bones of the control group and of the females rats that underwent different suspension periods (7, 14 and 21 days)

Figure 4 shows the mean load value in the elastic limit (EL) obtained in the tests with tibia and fibula bones of the rats of the group 1 (control) that was $(46,75 \pm 5,00) \mathrm{N}$. In the group 2 it was $(41,39 \pm 5,59) \mathrm{N}$, in the group 3 it was $(37,58 \pm 7,25) \mathrm{N}$ and in the group 4 it was $(32,17 \pm 5,27) N$. The simultaneous comparison among all the groups was statiscally different $(p=0,009)$. After analyzing the load values in $E L$, it was verified that there was a significant difference between the group 1 (control) and the group $2(p=0,0064)$, between the group 1 (control) and the group $3(p=0,0085)$ and between the group 1 (control) and the group $4(p=0,0096)$. It was also observed a statistically significant difference between the group 2 and $3(p=0,029)$, between the groups 2 and $4(p<0,0011)$ and between the groups 3 and 4 $(p=0,002)$.

The deflections in $E L$ presented mean values of $(0,478 \pm 0,046) \times 10^{-3} \mathrm{~m}$ in the group 1 (control), $(0,484 \pm 0,075) \times 10^{-3} \mathrm{~m}$ in the group 2, $(0,457 \pm 0,099) \times 10^{-3} \mathrm{~m}$ in the group 3 and $(0,455 \pm 0,094) \times 10^{-3} \mathrm{~m}$ in the group 4 . The simultaneous comparison among all the groups wasn't statiscally different $(p=0,580)$. By comparing the deflection values in EL, it was verified that there wasn't a statiscally significant difference among the groups. The values were: $(p=0,816)$ between the groups 1 and $2,(p=0,529)$ between the groups 1 and $3,(p=0,464)$ between the groups 1 and $4,(p=0,291)$ between the groups 2 and $3,(p=0,485)$ between the groups 2 and 4 and $(p=0,928)$ between the groups 3 and 4 (figure 5 ).

The load mean value in the maximum limit $(M L)$ was $(60,01 \pm 7,84)$ in the group 1 (control), $(51,29 \pm .4,37) \mathrm{N}$ in the group 2, $(51,05 \pm .8,78) \mathrm{N}$ in the group 3 and $(43,77 \pm .4,49) \mathrm{N}$ in the group 4 . The simultaneous comparison among all the groups was statiscally different $(p=<0,001)$. It could be observed that there was a statiscally significant difference between the group 1 and $2(p=<0,001), 1$ and 3 $(p=0,008)$ and 1 and $4(p=<0,001)$. There was also a statiscally significant difference between the groups 2 and 4 and 3 and 4 , but there wasn't difference between the groups 2 and 3. (Figure 6). 
po $2(p=0,816)$, entre o grupo 1 e o grupo $3(p=0,529)$ e entre o grupo 1 e o grupo $4(p=0,464)$, entre os grupos 2 e 3 ( $p=0,291), 2$ e 4 $(p=0,485)$, entre os grupos 3 e 4 $(p=0,928)$ (Figura 5)

O valor médio da carga no limite máximo (LM) no grupo 1 (controle) foi $(60,01 \pm 7,84)$, para o grupo 2 foi $(51,29 \pm .4,37) \mathrm{N}$, para o grupo 3 foi $(51,05 \pm .8,78) \mathrm{N}$ e para o grupo 4 foi $(43,77 \pm .4,49) \mathrm{N}$. A comparação simultânea entre todos os grupos foi estatisticamente diferente $(p=<0,001)$. Pode-se constatar que houve diferença estatisticamente significante entre 0 grupo 1 e o grupo $2(p=<0,001)$, entre o grupo 1 e o grupo3 $(p=0,008)$ e entre o grupo 1 e o grupo $4(p=<0,001)$. Pode-se observar que também houve diferença estatisticamente significante entre os grupos 2 e 4 e entre os grupos 3 e 4 , porém não houve diferença entre o grupo 2 em relação ao grupo 3 (Figura 6).

As deflexões no LM dos ensaios das ratas do grupo 1 (controle) apresentaram valor médio de $(0,697 \pm 0,071) \times 10^{-3} \mathrm{~m}$, para o grupo 2 foi $(0,729 \pm 0,088) \times 10^{-3} \mathrm{~m}$, para o grupo $3(0,711 \pm 0,075) \times 10^{-3} \mathrm{~m}$ e para o grupo $4(0,765 \pm 0,114) \times 10$ ${ }^{3} \mathrm{~m}$. A comparação simultânea entre todos os grupos não foi estatisticamente diferente $(p=0,105)$. Os valores das deflexões no LM foram comparados e constatou-se que não houve diferença estatisticamente significante entre os grupos. O valor obtido entre o entre o grupo 1 e o grupo 2 foi $(p=0,306)$, entre o grupo 1 e o grupo 3 foi $(p=0,615)$ e entre o grupo 1 e o grupo $4(p=0,086)$. Não houve diferença estatística entre os grupos 2 e $3(p=0,481)$, entre os grupos 2 e $4(p=0,176)$, e entre os grupos 3 e $4(p=0,098)$ (Figura 7).

O valor médio da rigidez nos ensaios do grupo1 (controle) foi $(102,99 \pm 17,88) \times 10^{3} \mathrm{~N} / \mathrm{m}$, para 0 grupo 2 foi $(87,36 \pm 12,04) \times 10^{3} \mathrm{~N} / \mathrm{m}$, para o grupo $3(82,89 \pm 19,78) \times 10^{3} \mathrm{~N} /$ $m$ e, para o grupo 4, foi $(71,18 \pm 11,47) \times 10^{3} \mathrm{~N} / \mathrm{m}$. A comparação simultânea entre todos os grupos foi estatisticamente diferente $(p<0,001)$. Comparando os valores da rigidez foi verificado que houve diferença estatisticamente significante entre o grupo 1 e o grupo $2(p=0,004)$, entre o grupo 1 e o grupo $3(p=0,008)$ e entre o gru-

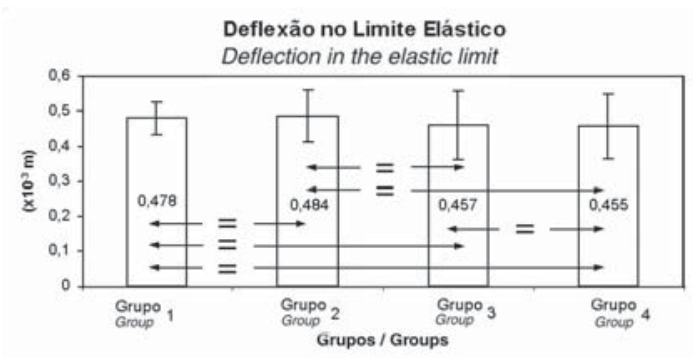

Figura 5 - Comparação entre os valores médios das deflexões no limite elástico nos diferentes grupos.

Figure 5 - Comparison among the mean values of the deflections in the elastic limit in different groups

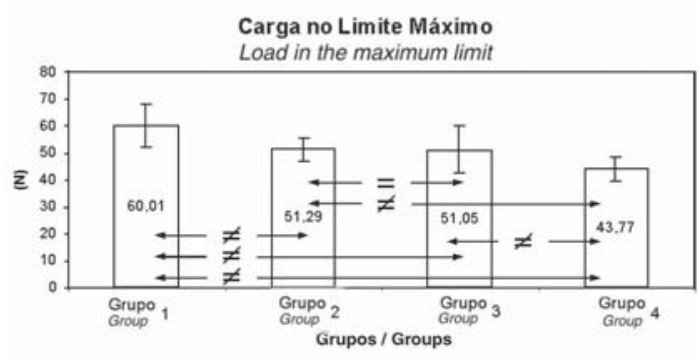

Figura 6 - Comparação entre os valores médios das cargas no limite máximo nos diferentes grupos.

Figure 6 - Comparison among the mean values of the loads in the maximum limit in different groups

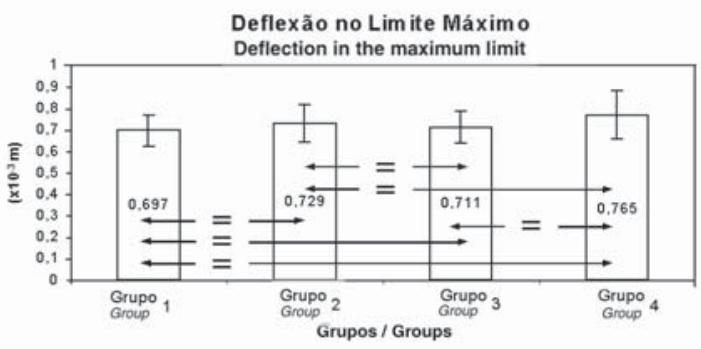

Figura 7 - Comparação entre os valores médios das deflexões no limite máximo nos diferentes grupos. Figure 7 - Comparison among the mean values of the deflections in the maximum limit in different groups.

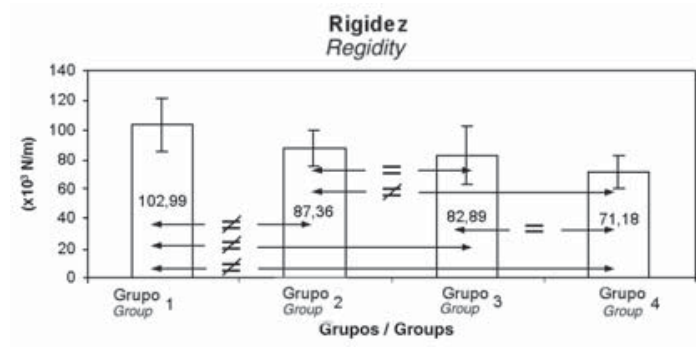

Figura 8 - Comparação entre os valores médios da rigidez nos diferentes grupos.

Figure 8 - Comparison among the mean values of rigidity in different groups.
The deflections in $M L$ in the tests of the rats presented a mean value of $(0,697 \pm 0,071) \times 10^{-3} \mathrm{~m}$ in the group 1 (control), $(0,729 \pm 0,088) \times 10^{-3} \mathrm{~m}$ in the group 2, $(0,711 \pm 0,075) \times 10^{-3} \mathrm{~m}$ in the group 3 and the $(0,765 \pm 0,114) \times 10$ in the group 4 . The simultaneous comparison among all the groups showed that there wasn't statiscally significant difference among the groups. The obtained value between the group 1 and 2 was $(p=0,306),(p=0,615)$ between 1 and 3 and $(p=0,086)$ between 1 and 4 . There wasn't statistic difference between the groups 2 and $3(p=0,481), 2$ and 4 $(p=0,176)$ and 3 and $4 \quad(p=0,098)$ (Figure 7).

The mean value of rigidity in the tests was $(102,99 \pm 17,88) \times 10^{3} \mathrm{~N} / \mathrm{m}$ in the group $1,(87,36 \pm 12,04) \times 10^{3} \mathrm{~N} / \mathrm{m}$ in the group 2, $(82,89 \pm 19,78) \times 10^{3} \mathrm{~N} / \mathrm{m}$ in the group 3 and $(71,18 \pm 11,47) \times 10^{3} \mathrm{~N} /$ $m$ in the group 4. The simultaneous comparison among all the groups was statiscally different $(p<0,001)$. By comparing the rigidity values, it could be observed that there was a statistically significant difference between the groups 1 and 2 $(p=0,004), 1$ and $3(p=0,008)$ and 1 and $4 \quad(p<0,001)$. There was a statistic difference between the groups 2 and 4 but there wasn't difference between the groups 2 and 3 or 3 and 4 (Figure 8).

The calculated resilience presented a mean value of $(1,041 \pm 0,116) \times 10^{-2} \mathrm{~J}$ in the tests of the group 1 (control), $(0,933 \pm 0,229) \times 10^{-2} \mathrm{~J}$ in the group 2, $(0,803 \pm 0,270) \times 10^{-2} \mathrm{~J}$ in the group 3 and $(0,648 \pm 0,335) \times 10^{-2} \mathrm{~J}$ in the group 4. The simultaneous comparison among all the groups was statiscally different $(p=0,002)$. There wasn't a statistic difference between the group 1 and 2 ( $p=$ $0,168)$. However there was a difference between the group 1 and the group $3(p=0,011)$ and between the groups 1 and $4(p=0,001)$. There was a statistically significant difference between the groups 2 and 4, but there wasn't difference between the groups 2 and 3 or 3 and 4. The obtained values between the groups 2 and 3 were $(p=0,105)$, $(p=0,002)$ between the groups 2 and 4 and $(p=0,052)$ between the groups 3 and 4. (Figure 9). 
po 1 e o grupo $4(p<0,001)$. Houve diferença estatística entre os grupos 2 e 4 , porém não houve diferença entre os grupos 2 e 3; e o grupo 3 em relação ao grupo 4 (Figura 8).

A resiliência calculada nos ensaios do grupo 1 (controle) apresentou valor médio de $(1,041 \pm 0,116) \times 10^{-2} \mathrm{~J}$, para o grupo 2 $(0,933 \pm 0,229) \times 10^{-2} \mathrm{~J}$, para o grupo 3 $(0,803 \pm 0,270) \times 10^{-2} \mathrm{~J}$ e para o grupo 4 $(0,648 \pm 0,335) \times 10^{-2} \mathrm{~J}$. A comparação simultânea entre todos os grupos foi estatisticamente diferente $(p=0,002)$. Não houve diferença estatística entre o grupo 1 e o grupo $2(p=0,168)$. Porém, houve diferença entre o grupo 1 e o grupo $3(p=0,011)$ e entre o grupo 1 e o grupo 4 $(p=0,001)$. Houve diferença estatisticamente significante entre os grupos 2 e 4, porém não houve diferença entre os grupos 2 e 3 e os grupos 3 e 4 . Os valores obtidos entre os grupos 2 e 3 foram $(p=0,105)$, entre os grupos 2 e $4(p=0,002)$, e entre os grupos 3 e 4 $(p=0,052)$ (Figura 9).

\section{DISCUSSÃO}

As pesquisas relacionadas com permanência dos astronautas no espaço mostram que realmente ocorre uma série de alterações músculo-esqueléticas, mesmo após o retorno à Terra. Essas pesquisas podem ser úteis para determinar medidas de prevenção ou tratamento da osteopenia, não somente para astronautas, mas também para pacientes com osteoporose ou ainda pacientes que necessitam permanecer acamados por longos períodos ${ }^{(2,14)}$.

A maior importância desta pesquisa está relacionada com a necessidade da compreensão e manipulação da forças que agem sobre o corpo humano como tônus muscular, resistência externa, atrito, com intuito de identificar fatores de risco, estabelecer medidas preventivas e instituir medidas terapêuticas de reabilitação adequadas ao enfraquecimento ósseo provocado pela inatividade.

Martin et al.(10) fez comparação entre os dados obtidos em animais que permaneceram em suspensão. As semelhanças encontradas nos testes sugerem que o modelo de suspensão é válido, principalmente para análise de alterações músculo-esqueléticas.

Nosso modelo de suspensão foi desenvolvido a partir do descrito por Kasper et al. ${ }^{(8)}$, com algumas modificações. Um exemplo foi a haste utilizada no eixo de suspensão. Em nosso estudo piloto, realizado de acordo com a descrição original, ela era lisa, o que dificultava o controle do deslocamento dos animais, vez que eles deslizavam involuntariamente até mesmo quando estavam dormindo. Essa haste foi então substituída por uma rosqueada, o que permitiu maior estabilidade do animal durante sua movimentação e ainda facilitou a fixação do eixo de suspensão. O tamanho da gaiola foi elaborado de tal forma a impedir que os animais se apoiassem em qualquer parte da gaiola. O sistema de suspensão pela cauda foi desenvolvido minuciosamente para evitar que ocorresse qualquer tipo de lesão na cauda do animal.

No levantamento bibliográfico foi observado um número muito pequeno de trabalhos que realizaram ensaios mecânicos em animais que permaneceram em ambientes de simulação de microgravidade.

O objetivo deste trabalho surgiu do interesse em analisar as alterações ósseas ocorridas durante períodos de permanência em ambientes de microgravidade, ou de restrição da atividade física, por meio do ensaio de flexão em três pontos. Esse ensaio foi escolhido por se mostrar eficiente nas análises propostas e também por ser simples.

\section{DISCUSSION}

The research related to the astronauts stay in the space shows that a series of musculoskeletal alterations may really occur, even after returning to the Earth. This research can be useful in order to determine prevention measures or a treatment to osteopenia, not only for astronauts but also to patients presenting osteoporosis or needing to rest in bed for long periods ${ }^{(2,14)}$.

The most important in this research is related to the necessity of understanding and managing the forces that act on the human body such as the muscular tone, the external resistance, the friction. The aim is to identify the risk factors settling prevention and therapeutical measures of rehabilitation adequate to the bone weakness caused by inactivity.

Martin et al. ${ }^{(10)}$ compared the data obtained in animals that underwent suspension. The similarities found in the tests suggest that the suspension model is valid, mainly to the analysis of musculoskeletal alterations.

Our suspension model was developed from Kasper et al. ${ }^{(8)}$ papers with some changes. An example was the shaft used in the suspension axle. In our pilot study, performed according to the original description, it was smooth, what caused difficulty in controlling the animals' movements since they slid unintentionally even while sleeping. This shaft was then substituted by a twisted one, what enabled a greater stability of the animal during its movements making it easier the suspension axle fixation. The cage size was projected in order to obstruct the animals support in any part of the cage. The system of tail suspension was meticulously developed in order to avoid any lesion in the animal tail.

During the bibliographical research, there were only few papers performing mechanical tests in animals maintained in microgravity simulation environment.

The aim of this paper came from the interest in analyzing the bone alterations occurred during stays in microgravity environment or in periods of physical activity restriction, by the essay of flexion in three points. This essay was chosen because it appears effective in the purposed analysis and because it is simple.

The animals selected for this paper were adult-and young since they present a reasonable size of the tibia and fibula, facilitating the management and fixation of the samples to a better view of the events occurred during the mechanical essay.

The mean weight of each animal was 250 gr., This size was considered adequate for the cage size and for the suspension system developed in this paper.

In Desplanches et al.(3) results, the animals presented a higher loss of weight during the first days of suspension but, after fourteen days, most of them restored the lost weight.

In our paper, the analysis of the animals weight variation among the groups and in different periods inter-groups showed that, at first, there was a significant weight loss which is natural and expected because of the stressing condition of the animal. However, after that it occurred a partial recovery showed by the significant weight increase in the group 4, when the mean weight is analyzed at the beginning and at the end of the experiment.

This is clear when we compare the present increase between the final mean weight in the groups 2 and 3 . The analysis of the weight in the group 3 (14 days) shows that it is a transitional period.

Summarizing, regarding the weight analysis, our results showed that at first the animal was resentful with the new imposed condition 
Os animais selecionados para esse trabalho foram adultos-jovens, pois apresentam um tamanho razoável de tíbia e fíbula, o que facilita a manipulação e fixação das amostras, para melhor visualização dos eventos ocorridos durante o ensaio mecânico.

O peso médio de cada animal foi de 250 gramas. Esse tamanho foi considerado adequado para o tamanho da gaiola e para o sistema de suspensão elaborado neste trabalho.

Nos resultados de Desplanches et al. ${ }^{(3)}$, os animais tiveram maior perda de peso nos primeiros dias de suspensão mas, após quatorze dias, a maioria deles recuperou o peso perdido.

Em nosso trabalho, a análise da variação do peso dos animais entre os grupos e, em diferentes períodos inter-grupos, mostrou que, no início, houve perda significativa do peso, o que é natural e esperado devido à condição estressante a que o animal é submetido. Entretanto, depois, ocorre recuperação parcial mostrada pelo incremento significativo de peso no grupo 4 quando se analisa o peso médio do início e final do experimento, nesse grupo. Isto também fica patente quando se compara o incremento existente entre o peso médio final dos grupos 2 e 3.

A análise do peso no grupo 3 (14 dias) mostra que esse período é transicional.

Em resumo, quanto à análise do peso, nossos resultados mostraram que o animal, inicialmente, ressente-se bastante da nova condição que lhe é imposta mas que, depois, sofre adaptação, recuperando-se quase que totalmente ao final de 21 dias. Esse mesmo resultado foi observado por Morey-Holton e Globus(11) que relata uma manutenção de peso dos animais após a adaptação à suspensão.

A pergunta que se faz a seguir é se seria conveniente manter esses animais em suspensão por períodos mais prolongados, com a finalidade de verificar se haveria recuperação completa do peso. Com essa medida, provavelmente, haveria complicações relacionadas principalmente com o próprio sistema de fixação da cauda, que teria que ser refeito, e, talvez, outras complicações, por exemplo respiratórias.

As médias do peso das peças (tíbia e fíbula) obtidas para o ensaio foram analisadas e o grupo 1 (controle) apresentou diferença estatística em relação aos outros grupos, o que se explica pela provável hipotrofia óssea sofrida com a imobilização.

Analisando em conjunto as propriedades mecânicas, verifica-se que, exceto pela deflexão no limite elástico e no limite máximo, houve diminuição de todas elas do primeiro para o quarto grupo, o que indica diminuição global da resistência óssea aos esforços aplicados, mostrando a efetividade do sistema de suspensão em provocar o enfraquecimento do osso, que foi mais acentuada no período mais longo. Ou seja, os animais saíram do sistema com o osso enfraquecido o que é muito importante em termos do que fazer a seguir, no caso de se considerar seres humanos a serem submetidos a um processo de reabilitação em decorrência da exposição a uma condição de microgravidade real ou em função de acamamento prolongado ou em grandes imobilizações. Nesse sentido, esses dados fornecem subsídios para, em condições experimentais, serem testados vários programas ou técnicas de reabilitação que devem, sempre, otimizar o binômio "menor tempo e menor risco". Assim, outros trabalhos poderão ser desenvolvidos a partir desta experiência, inclusive com o ensaio de drogas que possam atuar no metabolismo ósseo.

Fazendo um detalhamento dos dados obtidos com o ensaio mecânico, nota-se que a alteração mais precoce surgida foi da carga no limite de elasticidade, enquanto que as outras foram tardias e mais bem caracterizadas aos 21 dias, sendo que o grupo de 14 dias realmente representou uma fase de transição, da mesma maneira que com relação ao peso corporal e, portanto, não se presta para análise definitiva. Como a deflexão não foi alterada também aos 21 but after that it underwent adaptation and recovered almost totally at the end of 21 days. The same result was observed by Morey-Holton e Globus ${ }^{(11)}$ that report maintenance of the animals' weight after the adaptation to the suspension.

The question that follows is if it would be convenient or not to maintain these animals in suspension for longer periods aiming to verify the probable complete recovery of weight. By this measure, probably, it would present complications related to the tail fixation system, that would have to be remade or maybe other complications such as respiratory ones.

The mean weight of the parts (tibia and fibula) obtained for the essay were analyses and the group 1 (control) presented a statistical difference compared to other groups. This can be explained by the probable bone hypertrophy caused by the immobilization.

Analyzing the mechanical properties as a whole, it was verified that, except to the deflection in the elastic system and the maximum limit, there was a decrease in all of them from the first to the fourth group, indicating an overall decrease of the bone resistance to the applied force. This shows the effectiveness of the suspension system in causing the bone weakness, more stressed for the longer period. Therefore the animals finish the experiment present bone weakness. This is an important factor in order to determine the following step in case of evaluating human beings undergoing a rehabilitation process due to a real microgravity condition exposure or due to a long period of rest in bed or immobilization.

This way, the data provide grants to test several programs or rehabilitation techniques in experimental conditions in order to optimize the concepts "shorter time and shorter risk". So, other papers can be developed from this experiment including the drug essay that can act in the bone metabolism.

By detailing the data obtained with the mechanical essay, it was verified that the earlier alteration was the one of the load in the elasticity limit, while the other alterations were later and well characterized in 21 days. The fourteen-day group really represented a transition phase even regarding the body weight and therefore it should not be useful for the definitive analysis.

As the deflection didn't present alterations in 21 days, it can suggest that a longer time of suspension would be more adequate to modify it. From the same reasoning used in the weight analysis, there would be a necessity to test other intervals in order to optimize this period but maybe a limiting factor is the animal tolerance.

However, twenty-one days appear to be a good experimentation period since at the end of this time, important properties such as the maximum load and rigidity will be significantly altered. These properties strictly show the bone weakness and the higher risk of fractures and, in a rude way, are equivalent to the finds of other authors in other circumstances ${ }^{(9)}$

The detailed relationship between the type of mechanical property and the microstructure of the bone is still to be determined but overall it depends on the type/quality of the collagen and the mineral part, mainly the calcium. Therefore, it is difficult to explain, regarding the microstructure, what happens to the bone with the suspension that can significantly weaken it but doesn't interfere in its deflection capacity. We think this should be a reason for a new investigation.

In the literature, Morey-Holton and Globus ${ }^{(11)}$ mention that microgravity environment or those ones that simulate its effects promote a decrease in the formation and in the reabsorption of the bone. These mechanisms should directly act in the collagen quantity. Other factor that may interfere in the bone resistance is the spacial distribution of the collagen and the formation of the bone gills that, according to Wolff's Law, depends on the mechanical requests. ations.

We only need to find if 21 days are enough to observe these alter- 
dias, pode-se sugerir que um tempo maior de suspensão seria mais adequado para modificá-la. Usando o mesmo raciocínio empregado para o peso, para otimizar esse período haveria necessidade de testar outros tempos mas, talvez, um fator limitante seja a tolerância do animal.

Entretanto, em termos práticos, 21 dias parecem ser um bom período de experimentação, pois ao fim deste tempo, importantes propriedades como carga máxima e rigidez estão significativamente alteradas e estas propriedades expressam com rigor o enfraquecimento do osso e maior risco de fraturas sendo, grosso modo, equivalente ao já encontrado por outros, em outras circunstâncias ${ }^{(9)}$.

A relação minuciosa entre o tipo de propriedade mecânica e a microestrutura do osso ainda está por ser determinada, mas depende globalmente do tipo/ quantidade de colágeno e da parte mineral, principalmente o cálcio. Assim, fica difícil explicar, em termos de microestrutura, o que acontece ao osso com a suspensão a ponto de enfraquecê-lo significativamente mas não interferir em sua capacidade de deflexão. Cremos que esse assunto deva ser motivo de investigação.

Na literatura, Morey-Holton e Globus ${ }^{(11)}$ referem que ambientes de microgravidade ou que simulem seus efeitos promovem tanto diminuição na formação quanto na reabsorção do osso. Esses mecanismos atuariam diretamente na quantidade de colágeno. Outro fator que pode estar interferindo na resistência óssea é a própria distribuição espacial do colágeno e formação das lamelas ósseas que, de acordo com a Lei de Wolff, depende das solicitações mecânicas. Resta saber se 21 dias são suficientes para que estas modificações sejam percebidas.

Outras pesquisas podem ser realizadas a partir do modelo desenvolvido neste trabalho. Como por exemplo, testar tempos mais longos de exposição à suspensão, caracterizar melhor do ponto de vista metabólico as alterações encontradas no metabolismo do cálcio e fósforo, estudar modificações na microestrutura do osso após a suspensão, testar diferentes métodos de reabilitação usando o modelo aqui estudado e ainda testar a influência de substâncias que atuam positivamente na neoformação óssea, como os disfosfanados.

\section{CONCLUSÃO}

O modelo de suspensão elaborado neste trabalho mostrou ser eficaz, simples e com boa tolerância dos animais.

A hipoatividade provocada causou reduções significativas nos valores da maioria das propriedades mecânicas no osso, levando ao seu enfraquecimento.

\section{REFERÊNCIAS BIBLIOGRÁFICAS}

1. Astrand Po, Rodahl K. Tratado de fisiologia do exercício. 2. ed. Rio de Janeiro, Interamericana, 1980. p.246-252.

2. Cowin SC. On mechanosensation in bone under microgravity. Bone 22:119125, 1998.

3. Desplanches D, Mayet MH, Sempore B, Flandrois R. Structural and functional responses to prolonged hindlimb suspension in rate muscle. J Appl Physiol 63:558-563, 1987

4. Gould III JA. Biomecânica básica na terapia esportiva e ortopédica. In: Fisioterapia na ortopedia e na medicina do esporte. São Paulo, Manole, 1993. p.3-83.

5. Hart KJ, Shaw JM, Vajda E et al. Swim-trained rats have greater bone mass density strength and dynamics. J Appl Physiol 91:1663-1668, 2001.

6. Holick MF. Perspective on the impact of weightlessness on calcium and bone metabolism. Bone 22:105-111, 1998.

7. Johnson RB. The bearable lightness of being: bones, muscles, and spaceflight. Anat Rec 253:24-27, 1998.

8. Kasper CE, McNulty AL, Otto AJ, Thomas DP. Alterations in skeletal muscle related to impaired physical mobility: an empirical model. Res Nurs Health 16:265-273, 1993.
Other studies can be performed from the model developed in this paper. As an example, testing longer exposure intervals in suspension, better characterizing the alterations found in calcium and phosphorus metabolism by a metabolic point of view, studying the bone microstructure alterations after the suspension, testing different rehabilitation methods using this studied model and still testing the substances influence that positively act in the bone neoformation such as the dysphosphonates

\section{CONCLUSION}

The suspension model developed in this paper showed effectiveness, simplicity and is well tolerated by the animals.

The provoked hypoactivity caused significant decreases in the values of most of the mechanical properties of the bone leading to its weakness.
9. Martin RB, Boardman DL. The effects of collagen fiber orientation porosity density and mineralization on bovine cortical bone bending properties. J Biomech 26:1047-1054, 1994.

10. Martin TP, Edgerton VR, Grindeland RE. Influence of spaceflight on rat skeletal muscle. J Appl Physiol 65:2318-2325, 1988.

11. Morey-Holton ER, Globus RK. Hindlimb unloading of growing rats: a model for predicting skeletal changes during space flight. Bone 22:83-88, 1998.

12. Musacchia XJ, Steffen JM, Deavers DR. Rat hindlimb muscle responses to suspension hypokinesia/hipodynamia. Aviation space and environmental. Medicine 54:1015-1020, 1983

13. Musacchia XJ, Stefen JM, Fell RD. Disuse atrophy of skeletal muscle: animal models. Exerc Sport Sci Rev 16:61-87, 1988

14. Stehle P. Summary of research issues in the animal model. Bone 22:101-102, 1998.

15. Turner RT. Mechanical signaling in the development of postmenopausal osteoporosis. Lupus 8:388-392, 1999. 